\title{
In vitro evaluation of the resistence of the Contracaecum sp. larvae (Railliet \& Henry, 1912) (Nematoda: Anisakidae), to the essential oil of citronella (Cymbopogon sp.) (Poaceae)
}

\author{
Avaliação in vitro da resistência de larvas de Contracaecum sp. \\ (Railliet \& Henry, 1912) (Nematoda: Anisakidae), ao óleo essencial \\ de citronela (Cymbopogon sp.) (Poaceae)
}

\author{
Christiano Henrique da Silva Justino, ${ }^{*}$ Luciano Antunes Barros**
}

\begin{abstract}
The essential oil of citronella (Cymbopogon sp.) was used in vitro to assess its influence on the L3 larvae of Contracaecum sp. The parameters investigated were the morphological integrity and motility of the larvae after being in contact with the product. The essential oil was very effective in its trade form killing all the larvae at the utmost in two hours. The damage caused to the larvae was evaluated with a microscope in histological cuts, where cuticular rupture and disintegration of the intestinal wall of the larvae were found. The results were analyzed through the use of a monocaudal Fisher test to detect differences between the groups where the significance of $\mathrm{p}<0,05$ was obtained.
\end{abstract}

Keywords: Contracaecum, Anisakidae, Cymbopogon, citronella.

\section{Resumo}

O óleo essencial de citronela (Cymbopogon sp.) foi utilizado in vitro para avaliar sua ação sobre larvas L3 de Contracaecum sp. Os parâmetros observados foram motilidade e integridade morfológica das larvas após contato com o produto. O óleo essencial demonstrou-se bastante eficaz, em sua forma comercial, causando morte de todas as larvas em no máximo duas horas. Os danos causados às larvas foram avaliados microscopicamente em cortes histológicos, encontrando-se ruptura cuticular e lise da parede intestinal das larvas. Os resultados foram analisados através da aplicação do teste de Fisher monocaudal para detectar diferenças entre os grupos, onde se obteve uma significância de $p<0,05$.

Palavras-chave: Contracaecum, Anisakidae, Cymbopogon, citronela.

\section{Introduction}

The consumption of the fish is, since old times, a common practice in many human populations, because of its nutritional characteristics. Some cultures, however, have the habit of eating uncooked fish, having the risk of catching some diseases (São Clemente et al., 1996; Okumura, et al., 1999).

The study of the parasitic diseases transmitted through the consumption of fish meat, becomes essential for public health, since man in several situations takes the role of an accidental host in the biological cycle of parasites, such as Eustrongilides ignotus, Anisakis simplex, Diphyllobotrium latum, Ascocotyle longa, among others, many times with relevant clinical manifestations (Eberhard et al., 1989; Chieffi et al., 1992; Del Pozo et al., 1996; Emmel et al., 2006).
The anisakiose is considered the most common among the parasitic diseases transmitted by fish, deriving from the infection by Anisakis sp. larvae, after the intake of raw fish meat. The symptoms presented may vary a lot, although the most common are the gastric pains, followed or not by vomit, which may progress to an acute abdominal syndrome, with abdominal pains, abnormal muscular tension and manifestations similar to appendicitis. The penetration of the mucosa of the gastrointestinal tract by the larvae, can lead to the formation of abscesses or granulomas eosinophilics, besides the gastro enteric ulcerations and eosinophilic colitis (São Clemente et al., 1995; López-Serrano et al., 2000). The occurrence of alterations of hypersensitivity, with nettle rash and even anaphylaxis, have been reported in patients with a history of cooked fish consumption, revealing the maintenance

\footnotetext{
* Universidade Federal do Mato Grosso, Mestrado em Ciências da Saúde, Faculdade de Ciências Médicas, Av. Fernando Corrêa da Costa S/N, 78069-900, Cuiabá, MT - chrisjustino@hotmail.com

** Universidade Federal do Mato Grosso, Faculdade de Agronomia e Medicina Veterinária, Departamento de Produção Animal, Av. Fernando Corrêa da Costa S/N, 78069-900, Cuiabá, MT - labarros@terra.com.br
} 
of the allergen potential in parasitic particles existent in the fish that is eaten. (Okumura et al., 1999; López-Serrano et al., 2000).

For the State of Mato Grosso high prevalence of parasitism by the Contracaecum sp. larvae, are verified in fishes consumide by population as piraputanga Brycon microlepis Perugia, 1894, cachara Pseudoplatystoma fasciatum Linnaeus, 1766, and traíra Hoplias malabaricus Bloch, 1794 (Rego and Vicente, 1988; Barros et al., 2004; Moraes-Filho et al., 2004).

The action of the Contracaecum sp. larvae upon the gastric mucosa of rabbits, infected for experiment, was demonstred by Barros et al. (2004), describing the pathogenic potential of this nematode for this species of mammal. These authors alert to the possibility of human infection, as described for Anisakis sp.

The use of alcoholic citronella compounds upon the Anisakis $\mathrm{sp}$. larvae, was described in the in vitro test by Hierro et al. (2004), observing the larvicide action after four hours in contact with the product.

Aiming at getting to know about the use of citronella on other species nematode of the Anisakidae family and the search for the use of alternative methods for the treatment of this parasitosis transmitted by fish. This paper aims at testing the in vitro action of the essential oil of citronella on the Contracaecum sp. larvae.

\section{Material and methods}

For this study, 38 specimens of traíras (Hoplias malabaricus) from the district of Barão de Melgaço, State of Mato Grosso were used. After they were caught, the fish were taken in thermal containers to the Laboratory of the Veterinary Parasitology at the Universidade Federal de Mato Grosso.

With a interval of 12 hours at the most after catching the fishes, post-mortem exams were done for the collection of Contracaecum sp. larvae, in the guts, celomatic cavity and skeletal musculature of the fish that were examined using the techniques described by Pavanelli et al. (1998), and the musculature was "cut in slices" and examined with the help of a candling table. After being collected, the larvae were put on Petri dishes, with saline solution $(0,65 \% \mathrm{NaCl})$ to be considered for its viability, in a stereo microscope SZ-4045 (Olympus ${ }^{\circledR}$ ).

The essential oil used in the experiment was bought in a chemist's shop (Fórmula Certa, Lote. N. 000789), the levels of purity were guaranteed through sensorial and physical analyses that were normal, according to EML - Distribuidora Ely Martins (NF 72849/50).

The larvae separated for the experiment, were divided in six groups, each one containing ten larvae and maintained in Petri dishes. Four plates were identified as $T_{1}$ to $T_{4}$ (as test group), one plate as control group, and another last plate containing ten larvae for the confirmation of taxonomical diagnosis.

For each plate test, five $\mathrm{ml}$ of the essential oil of citronella were added and the control group was maintained in the same volume of saline solution $(0,65 \% \mathrm{NaCl})$, later the plates were put in an incubator chamber Biochemical Oxygen Demand (Fanem, Model $347 \mathrm{CD}$ ) with an average temperature of $28,4^{\circ}$ $\mathrm{C}\left( \pm 0,8^{\circ} \mathrm{C}\right)$ and relative humidity of $62 \%( \pm 4 \%)$.

At the end of each hour, one test plate was taken out of the B.O.D., and the larvae were washed with saline solution $(0,65 \%$
$\mathrm{NaCl}$ ), to interrupt the process of the product action. The larvae were examined through the stereomicroscope using the motility and structural integrity as parameter. The control group was also observed every hour during all the experimental period.

All the dead larvae were fixed in formalin $10 \%$, and later processed according to the histological techniques described by Prophet (1992). Then they were made into blocks of paraffin and cut in $5 \mu \mathrm{m}$, width on a manual microtome (Microm HM $325)$, that were coloured by the hematoxylin-eosin technique (Allen, 1992). The exams to evaluate the possibility of microscopic damages and microphotographs were done by optical microscope (Olympus BX41).

The larvae that were separated for taxonomic identification were fixed and processed according to the methodology described by Amato et al. (1991) and identified according to Hartwich (1974) and Vicente and Pinto (1999).

To evaluate the performance, among the treated groups and those untreated by the Citronella, the Fisher monocaudal test was done, using the statistic program Epi Info ${ }^{\mathrm{TM}}$ 6.0.

The fishes was identified according to Britski et al. (1999).

\section{Results and discussion}

After being in contact with the essential oil of citronella for one hour, only four larvae were alive, $T_{1}$ plate showing a $60 \%$ effectiveness of the larvicide action of this product.

After two hours, the $T_{2}$ plate was examined and it was verifying that all the larvae were dead. The $\mathrm{T}_{3} \mathrm{eT}_{4}$ plates were examined respectively with three and four hours after the beginning of the experience, and like as was observed on plate $T_{2}$, all the larvae were dead. An increase in body volume in thickness was observed. The larvae of the control plate remained viable, with motility and structural integrity unaltered during the experimental period.

The microscopic evaluation showed that the citronella essential oil caused cuticular rupture and disintegration of the intestinal wall, with occasional projection of the organs to the exterior part of the parasite, producing casual protuberances that were more evident after each hour (Figs. 1-4).

Through the comparison of the mortality rate of the Contracaecum sp. larvae, the efficiency of the treatment with Citronella on the non-treated parasites $(p=0,04)$ was shown.

All the larvae reserved for the taxonomic identification were diagnosed as Contracaecum sp. larvae in the third stage of development.

In this work the product was used pure, which justifies the larvicide action in less time when compared to the results obtained by Hierro et al. (2004) that used different monoterpenic products, diluted in different concentrations, on Anisakis sp. larvae observing total death of the larvae in four hours. Different results can be expected, also due to the use of different parasite species.

The citronella essential oil is efficient against the Contracaecum sp. larvae, however, tests using different dilutions, as well as the search for isolation of the different compositions that form the pure essential oil, through the gaseous chromatography, are the reason for new investigations about the use of citronella components on parasites of Anisakidae family. 


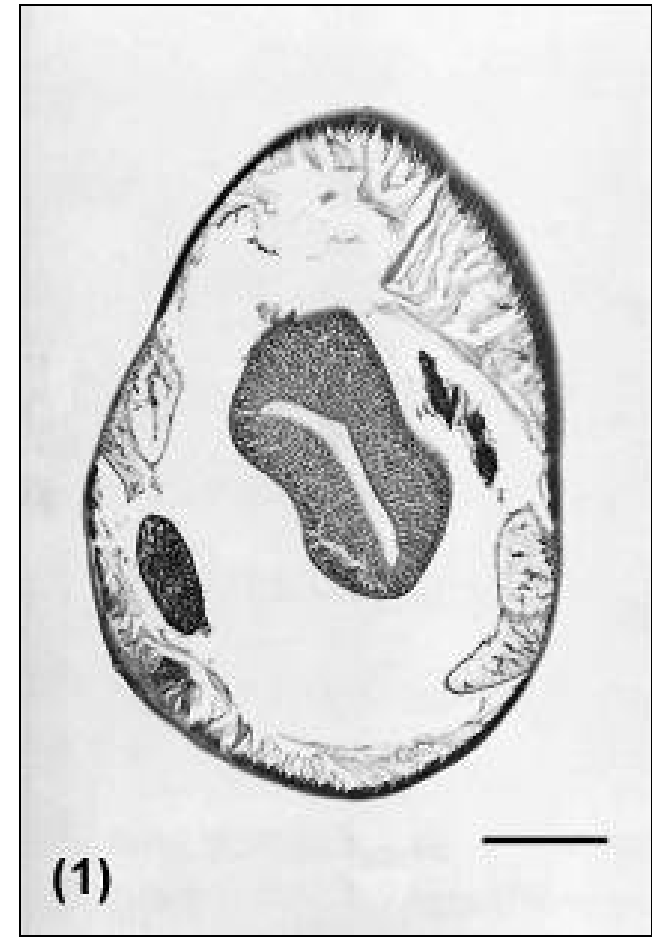

Figure 1: Transversal cut of the Contracaecum sp. $\mathrm{L}_{3}$ larvae of the control group showing cuticular and internal organs integrity. (bar $=2 \mu \mathrm{m})$

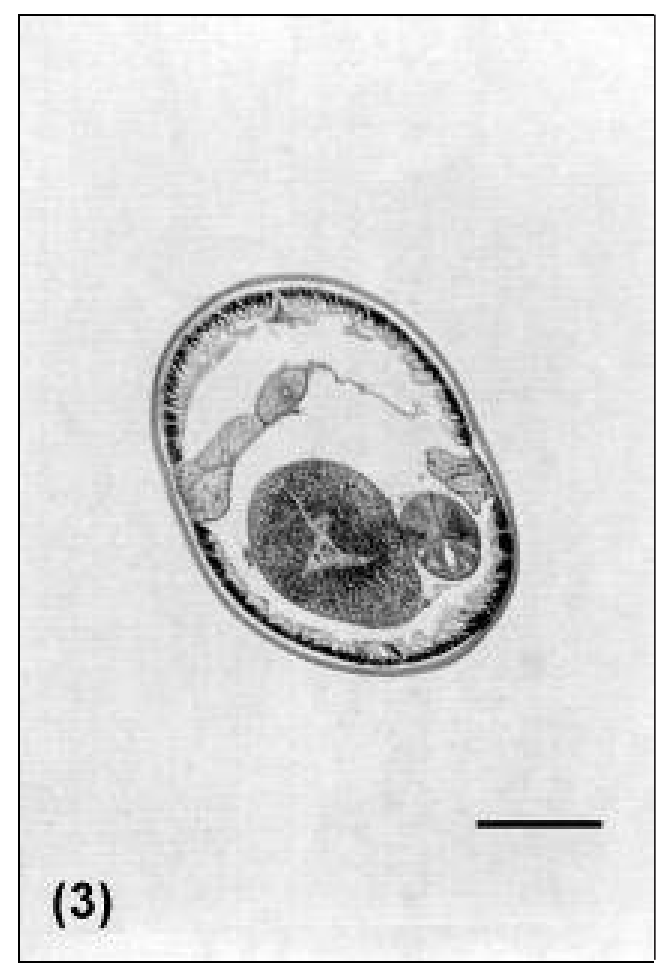

Figure 3: Transversal cut of the Contracaecum sp. $\mathrm{L}_{3}$ larvae after being two hours in contact with citronella oil, showing total loss in the cuticular adherence. (bar = $2 \mu \mathrm{m})$

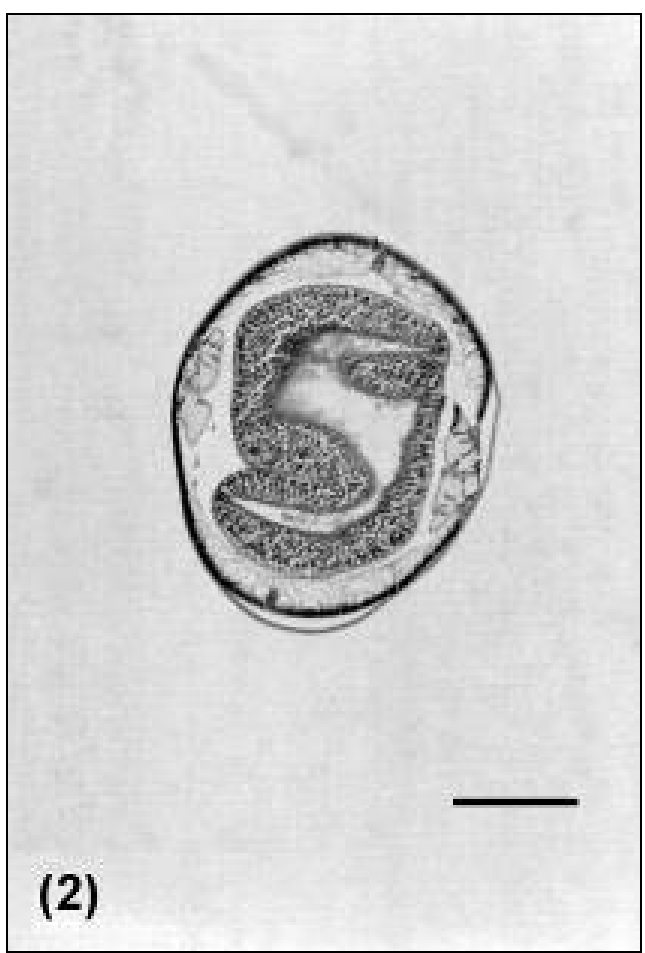

Figure 2: Transversal cut of the Contracaecum sp. $\mathrm{L}_{3}$ larvae after being one hour in contact with citronella oil showing a small loss in the cuticular adherence. (bar $=2 \mu \mathrm{m})$

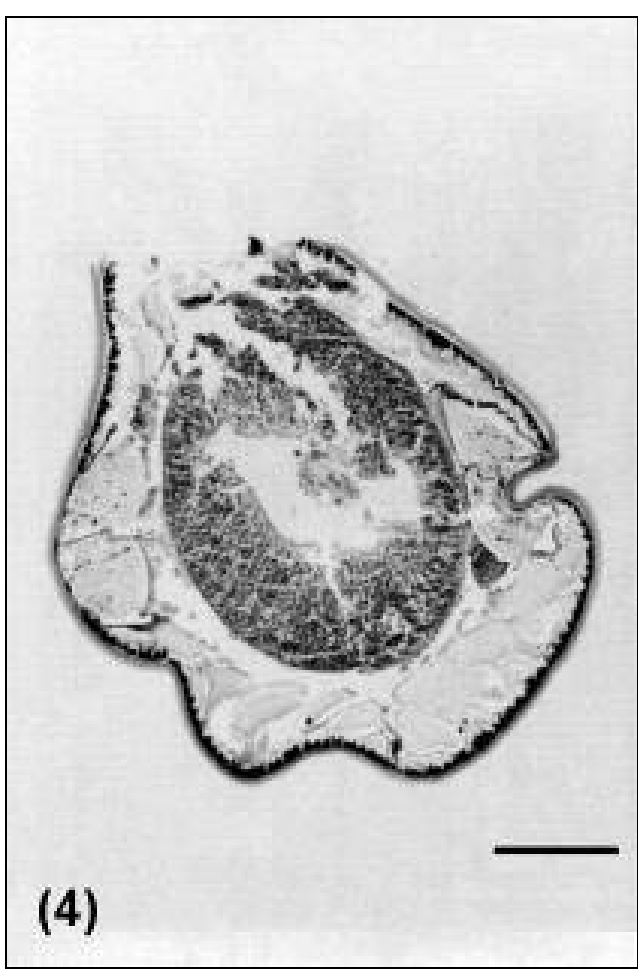

Figure 4: Transversal cut of the Contracaecum sp. L larvae after being four hours in contact with citronella oil, showing disintegration of the intestinal walls and cuticular rupture. (bar $=2 \mu \mathrm{m})$ 


\section{Acknowledgements}

To Professor Dr. Edson Moleta Colodel, from Laboratory of Veterinary Pathology of the Universidade Federal de Mato Grosso, for his help and the performing of the histological techniques. To professors Dra. Maria Luzinete A. Vanzeler and Dra. Cláudia Joseph Nehme, from the Laboratory of Pharmacology of the Universidade Federal de Mato Grosso for the technical support. To professor Dr. Sávio Amado, from the Department of Veterinary Medicine of the Universidade Federal de Mato Grosso, for his help with the statistical analysis. To the Veterinarian Ms. Paula Rodrigues Pinto, trainee of the Laboratory of Veterinary Parasitology of the Universidade Federal de Mato Grosso for the help in the necropsies to get the larvae.

\section{References}

ALLEN, TC. Hematoxylin and eosin. In: PROPHET, EB et al., editors. Laboratory methods in histotechnology. Washington, DC: Armed Forces Institute of Pathology; 1992. p. 53-58.

AMATO, JFR, BOEGER, WP, AMATO, SB. Protocolos para laboratório: coleta e processamento de parasitos de pescado. Seropédica: Imprensa Universitária, UFRRJ; 1991.

BARROS, LA, TORTELLY, R, PINTO, RM, GOMES, DC. Effects of experimental infections with larvae of Eustrongylides ignotus Jäegerskiold, 1909 and Contracaecum multipapillatum (Drasche, 1882) Baylis, 1920 in rabbits. Arq. Bras. Med. Vet. Zootec. 2004; v. 56, n. 3, p. 325-332.

BRITSKI, HA, SILIMON, KZS, LOPES, BS. Peixes do pantanal: manual de identificação. Brasília, DF: EMPRAPA-SPI; Corumbá: EMBRAPA-CPAP; 1999.

CHIEFFI, PP, GORLA, MCO, VIEIRA, TORRESDMAG etal. Human infection by Phagicola sp. (Trematoda, Heterophyidae) in the municipality of Registro, São Paulo State, Brazil. J. Trop. Med. Hyg, v. 95, n. 5, p. 346348, 1992.

DEL POZO, MD; ALDICANA, M; DIEZ, JM et al. Anisakis simples a relevant etiologic factor in acute urticaria. Allergy, v. 52, p. 576-579, 1996.

EBERHARD, ML, HURWITZ, H, SUN, A et al. Intestinal perforation caused by larval Eustrongylides (Nematoda: Dioctophymatoidae) in New Jersey. Am. J. Trop. Med. Hyg. v. 40, n. 6, p. 648-650, 1989.

EMMEL, VE, INAMINE, E, SECCHI, C et al. Diphyllobothrium latum: relato de caso no Brasil. Ver. Soc. Bras. Med. Trop, v. 39, n. 1, p. 82-84, 2006.

HARTWICH G. Keys to genera of the Ascaridoidea. In: ANDERSON et al., editores. CIH keys to the nematode parasites of vertebrates. UK; Commonwealth Agricultural Bureaux, Farnham Royal; 1974. p. 1-15.
HIERRO, I, VALERO, A, PÉREZ, P et al. Action of different monoterpenic compounds against Anisakis simplexs.I. L ${ }_{3}$ larvae. Phytomedicine, v. 11, n. 1, p. 77-82, 2004

LÓPEZSERRANO, MC, GOMEZ, AA, DASCHNER, A etal. Gastroallergic anisakis: Findings in 22 patients. J. Gastroent. Hepatol, v. 15, n. 5, p. 503-506, 2000.

MORAES-FILHO, J, OLIVEIRA, RL, BARROS, LA Dados preliminares sobre a presença de parasitos com potencial zoonótico em peixes de importância econômica provenientes do rio Cuiabá. In: 3ํㅡNCONTRO INTERNACIONAL DE NEGÓCIOS DE PECUÁRIA[CDROM]. 2004 mar912; Cuiabá. Cuiabá: ENIPEC, 2004.

OKUMURA, MPM, PÉREZ, ACA, ESPÍNDOLA FILHO, A. Principais zoonozes parasitárias transmitidas por pescado - revisão. Revista Educação Continuada do CRMV-SP1999, v. 2, n. 2, p. 66-80.

PAVANELLI, GC, EIRAS, JC, TAKEMOTO, R M. Doenças de Peixes: profilaxia, diagnóstico e tratamento. Maringá: EDUEM; 1998.

PROPHET, EB. Fixation. In: PROPHET, EB et al., editors. Laboratory methods in histotechnology. Washington, DC: Armed Forces Institute of Pathology; 1992. p. 29-31.

REGO, AA, VICENTE, JJ. Excursão científica à zona do pantanal, Estado de Mato Grosso, para coleta de helmintos. Ciênc. Cultura, v. 40, n. 1, p. 65-68, 1988.

SÃOCLEMENTE, SC, MARQUES, MC, SERRA-FREIRE, NM etal. Análise do parasitismo de peixe espada Trichiurus lepturus (L.) do litoral do Rio de Janeiro - Brasil. Parasitol. al Día 1995; v. 19, p.146-149.

SÃO CLEMENTE, SC, SILVA, CM; LUCENA, FP. Sobrevivência de larvas de anisakídeos de peixe espada Trichiurus lepturus (L.), submetidos aos processos de salmouragem e cocção. Rev. Bras. Ciênc. Vet.,v. 3, p. 79-80, 1996.

VICENTE, JJ, PINTO, RM. Nematóides do Brasil. Nematóides de peixes. Atualização: 1985-1998. Rev. Bras. Zool., v. 16, p. 561-610, 1999. 